\title{
Recovery and Expression of Messenger RNA from Postmortem Human Brain Tissue
}

Thomas J. Cummings, M.D., Jay C. Strum, Ph.D., Lawrence W. Yoon, Mari H. Szymanski, Christine M. Hulette, M.D.

Department of Pathology (TJC, MHS, CMH), Duke University Medical Center, Durham, North Carolina; and Quantitative Gene Expression Group (JCS, LWY), Department of Functional Genetics, GlaxoWellcome, Inc., Research Triangle Park, North Carolina

The Bryan Alzheimer's Disease Research Center Rapid Autopsy Program at Duke University Medical Center obtains postmortem human brain tissue for experimental investigations. We evaluated 19 brains for RNA integrity and mRNA gene expression. Nine were from patients diagnosed with Alzheimer's disease, and ten were from nondemented controls. In all cases, the following variables were recorded: postmortem procurement delay (range, 1 hour and 10 minutes to 14 hours), pH of cerebrospinal fluid, premortem fever or sepsis, provision of supplemental oxygen in the agonal period, and temporal relation to time of death (either sudden death or protracted illness). Total RNA was extracted, quantified, and evaluated by agarose gel electrophoresis and quantitative gene expression analysis of 18S rRNA and edg-1 using TaqMan technology. All samples appeared to yield intact RNA without significant degradation, and expression of the edg-1 gene was detected by the real time reverse transcriptase polymerase chain reaction in all cases. We conclude that intact RNA can be obtained from postmortem human brain tissue, even in patients with severe premortem illnesses and delayed postmortem tissue procurement intervals. However, we caution that the successful expression of certain genes from postmortem brain tissue may require enhanced procurement efforts to maximize RNA integrity.

KEY WORDS: Alzheimer's disease, Autopsy, edg-1, Gel electrophoresis, Messenger RNA, Real-time polymerase chain reaction.

Mod Pathol 2001;14(11):1157-1161

Copyright $(\odot 2001$ by The United States and Canadian Academy of Pathology, Inc.

VOL. 14, NO. 11, P. 1157, 2001 Printed in the U.S.A.

Date of acceptance: June 6, 2001.

This work was presented in part at the annual meeting of the United

States and Canadian Academy of Pathology, New Orleans, LA, March 2000.

Address reprint requests to: Thomas J. Cummings, M.D., Duke University Medical Center, Department of Pathology, Box 3712, Durham, NC 27710; e-mail: cummi008@mc.duke.edu; fax: 919-681-7634.
Animal models that are commonly used to study the pathogenesis of a wide variety of disorders do not always or exactly copy the human condition. Therefore, human tissue obtained at autopsy is needed for experimental investigations. This is particularly important for human drug development assays in which high throughput screening methods are employed to detect differential expression of biological molecules in diseased and normal individuals. Duke University Medical Center (DUMC) and the Bryan Alzheimer's Disease Research Center (ADRC) provide 24-hour service to perform rapid autopsies so that human brain tissue can be retrieved quickly, dissected, and snap-frozen for research studies (1). The major objective of the Rapid Autopsy Program (RAP) of the Bryan ADRC is to rapidly obtain tissue to prevent postmortem deterioration of biomolecules such as RNA. Biologically active mRNA is believed to be retained in human brain tissue for only a short time postmortem $(2,3)$.

The postmortem delay to refrigeration of the corpse was thought to impair assays of neurotransmitterrelated enzymes in early studies using postmortem human brain tissue (4). Other factors, including agonal hypotension and hypoxia that result in hypercapnia and reduced tissue $\mathrm{pH}$, premortem illnesses, and the temporal relation to time of death, have also been thought to adversely effect the biological status of postmortem human brain tissue $(2,4,5)$.

Advances in molecular pathology techniques such as the reverse transcriptase polymerase chain reaction (RT-PCR) require the procurement of tissue with intact biomolecules. Efforts to preserve RNA for functional genomic studies are therefore of paramount importance (6). Prior studies have evaluated mRNA levels in brain autopsies in rats (7) and in brain biopsies $(7,8,9,10)$. A recent study compared quantification of specific mRNA levels among sixteen different genes in human brain autopsies and biopsies by RT-PCR (11). Although there was a general decrease in measured mRNA levels for all genes in autopsies compared to biopsies, there 
were no significant differences after adjusting with reference genes (11). Nonetheless, one of the genes (CYP26A1, a member of the cytochrome P-450 gene family) showed a significantly decreased expression level in autopsies with a prolonged postmortem procurement interval (11).

The purpose of our study was to determine mRNA expression in postmortem brain tissue and to evaluate which variables might impair the postmortem integrity of human brain mRNA and thus hinder the detection of gene expression. The random gene we tested for was edg-1, a G proteincoupled receptor for sphingosine-1-phosphate that is essential for blood vessel development and maturation $(12,13,14)$. The edg-1 gene was selected primarily because of its prior success in our laboratory in assays involving other organs and without prior data of its expression in postmortem human brain tissue. Although high levels of edg- 1 mRNA gene have been detected in neuronal cells and brain capillaries of adult and embryonic rodent brain $(12,15,16)$, edg- 1 expression has not apparently been determined in postmortem human brain tissue.

\section{MATERIALS AND METHODS}

All patients were enrolled in the Bryan ADRC RAP at DUMC. Informed consent was obtained in compliance with institutional guidelines. All autopsies were performed as previously described (1). Nineteen autopsy brains with postmortem delays ranging from 1 hour and 10 minutes to 14 hours were obtained. Nine were from patients diagnosed post- mortem with Alzheimer's disease (AD) according to National Institute on Aging/Reagan Institute criteria (17). Ten were from nondemented controls (C). Neurofibrillary change in AD patients and controls was staged according to Braak (18). Apolipoprotein E status was available in 13 patients.

Some AD patients received supplemental oxygen $\left( \pm \mathrm{O}_{2}\right)$ via nasal cannula before death, and some $\mathrm{C}$ patients were mechanically ventilated before death. Thus there were four groups: $\mathrm{AD}+\mathrm{O}_{2}, \mathrm{AD}-\mathrm{O}_{2}$, $\mathrm{C}+\mathrm{O}_{2}, \mathrm{C}-\mathrm{O}_{2}$ (Table 1A-D, respectively). Detailed clinical information about the perimortem period was available in all cases. In three AD cases (Cases 887,843 , and 862 ), oral body temperature was monitored during the agonal period and ranged from $101.0^{\circ} \mathrm{F}$ to $102.5^{\circ} \mathrm{F}$; the temperature was monitored only in cases when it did not interfere with patient comfort. In all cases, a complete postmortem examination was performed. Infectious or inflammatory processes such as acute bronchopneumonia and acute cystitis were confirmed histologically. Cerebrospinal fluid (CSF) was obtained from the lateral ventricle and the $\mathrm{pH}$ was measured.

Human frontal cortex was obtained during autopsy from all patients and snap frozen in liquid nitrogen. Total RNA was isolated using RNeasy kits from Qiagen (Valencia, CA) The absorbance at 260/ $280 \mathrm{~nm}$ was determined spectrophotometrically for each sample, and approximately $1 \mu \mathrm{g}$ was loaded onto an agarose gel containing formaldehyde and resolved by electrophoresis. The gel was stained with ethidium bromide and the $18 \mathrm{~S}$ and $28 \mathrm{~S}$ bands were visualized using UV light. In parallel with the description above of Table 1 , the gels of groups

TABLE 1. Comparison of Control and Alzheimer's Patients Who Received or Did Not Receive Supplemental Oxygen during the Agonal Period

\begin{tabular}{|c|c|c|c|c|c|c|c|c|c|}
\hline Case & Age/Sex & $\mathrm{PMD}^{\mathrm{a}}(\mathrm{h})$ & RNA ( $\mu \mathrm{g} / \mathrm{g})$ & $\begin{array}{c}\mathrm{CSF} \\
\mathrm{pH}\end{array}$ & $\begin{array}{l}\text { Sudden } \\
\text { Death }\end{array}$ & $\begin{array}{l}\text { Postmortem } \\
\text { Inflammation }\end{array}$ & Braak Stage & APOE & Duration $\mathrm{AD}(\mathrm{y})$ \\
\hline 887 & $70 / \mathrm{M}$ & $2: 35$ & 455 & 7.1 & No & Acute BP & 5 & N/A & 11 \\
\hline 843 & $94 / F$ & $3: 19$ & 190 & 5.9 & No & Candidiasis & 3 & 3,4 & 20 \\
\hline 874 & $68 / \mathrm{F}$ & $9: 45$ & 293 & 7.2 & No & Acute BP & 4 & 4,4 & 12 \\
\hline 928 & $93 / \mathrm{F}$ & $12: 16$ & 309 & 7.0 & No & Acute BP & 4 & N/A & 15 \\
\hline 862 & $87 / F$ & $13: 35$ & 896 & 6.9 & No & Acute BP & 5 & N/A & 9 \\
\hline \multicolumn{10}{|c|}{ Control patients who received supplemental oxygen } \\
\hline 673 & $80 / \mathrm{F}$ & $1: 10$ & 190 & 6.9 & No & Acute cystitis & 1 & 3,3 & 0 \\
\hline 406 & $77 / \mathrm{M}$ & $1: 15$ & 325 & 7.7 & No & Acute BP & 1 & 2,2 & 0 \\
\hline 542 & $81 / \mathrm{M}$ & 3:15 & 903 & 8.0 & No & Acute BP & 0 & 3,3 & 0 \\
\hline 911 & $90 / \mathrm{M}$ & $7: 25$ & 421 & 7.1 & No & None & 2 & $\mathrm{~N} / \mathrm{A}$ & 0 \\
\hline 838 & $91 / \mathrm{M}$ & $7: 41$ & 632 & 6.0 & Yes & Chronic cystitis & 1 & 3,3 & 0 \\
\hline 787 & $93 / F$ & $10: 38$ & 1798 & 6.8 & No & Acute BP & 1 & 3,3 & 0 \\
\hline 904 & $45 / \mathrm{M}$ & $14: 00$ & 566 & 7.0 & No & None & 0 & N/A & 0 \\
\hline \multicolumn{10}{|c|}{ Alzheimer's patients who did not receive supplemental oxygen } \\
\hline 901 & $80 / \mathrm{F}$ & $2: 30$ & 751 & 7.3 & No & Acute BP & 5 & 4,4 & 13 \\
\hline 847 & $83 / \mathrm{M}$ & 9:10 & 358 & 7.0 & No & Acute cystitis & 3 & 3,3 & N/A \\
\hline 927 & $59 / \mathrm{M}$ & 9:45 & 1204 & 7.2 & No & Acute BP & 5 & 4,4 & 10 \\
\hline 845 & $82 / \mathrm{F}$ & $12: 35$ & 284 & 6.7 & No & Acute BP & 6 & N/A & 15 \\
\hline \multicolumn{10}{|c|}{ Control patients who did not receive supplemental oxygen } \\
\hline 926 & $72 / \mathrm{F}$ & 2:00 & 796 & 7.1 & Yes & None & 2 & 3,3 & 0 \\
\hline 795 & $81 / \mathrm{M}$ & $7: 14$ & 377 & 6.3 & No & None & 1 & 3,4 & 0 \\
\hline 794 & $85 / \mathrm{M}$ & $10: 07$ & 253 & 6.9 & Yes & None & 1 & 3,3 & 0 \\
\hline
\end{tabular}

PMD, postmortem delay; BP, bronchopneumonia; N/A, not available; APOE, apolipoprotein E; AD, Alzheimers disease.

${ }^{a}$ Cases are arranged in order of increasing time of postmortem delay within each group. 
$\mathrm{AD}+\mathrm{O}_{2}, \mathrm{AD}-\mathrm{O}_{2}, \mathrm{C}+\mathrm{O}_{2}$, and $\mathrm{C}-\mathrm{O}_{2}$, are shown (Fig. $1 \mathrm{~A}-\mathrm{D}$, respectively). The total RNA was further processed for real time reverse transcriptase (RT-PCR) analysis by treating the samples with Rnase-free DNase (Ambion), quantitating the DNA-free RNA using Ribogreen (Molecular Probes), and adjusting the volumes of each sample to $5 \mathrm{ng}$ of total RNA/ $\mu$ l. $18 \mathrm{~S}$ rRNA and $e d g-1$ was quantitated using TaqMan technology. The probe and primer set used for $18 \mathrm{~S}$ rRNA quantitation was obtained from Applied Biosystems (Foster City, CA). The probe and primer set used for $e d g-1$ quantitation was as follows: forward (5'TCTGCGGGAAGGGAGTATGT-3'), reverse (5'CGATGGCGAGGAGACTGAA-3'), and probe (5'FAMTGTGGCCCTGTCAGCCTCCGT-TAMRA-3'). This set was designed using Primer Express software (Applied Biosystems, Foster City, CA). One-step RTPCR was performed using buffer A, $5 \mathrm{~mm} \mathrm{MgCl}_{2}$, 1 $\mu \mathrm{M}$ dNTPs, and $300 \mathrm{~nm}$ of each primer and $150 \mathrm{~nm}$ probe. 50 ng of total RNA template was added and RT-PCR was performed at the following conditions: $48^{\circ} \mathrm{C}$ for 30 minutes followed by $95^{\circ} \mathrm{C}$ for $10 \mathrm{~min}-$ utes, and 40 cycles of $95^{\circ} \mathrm{C}$ for 15 seconds and $60^{\circ} \mathrm{C}$ for 1 minute. Real-time data of $18 \mathrm{~S}$ rRNA expression and edg- 1 mRNA expression were collected using the ABI7700 (Applied Biosystems, Foster City, CA). Amplification plots collected by the ABI7700 during the PCR portion of the assay are shown and again include the four groups $\mathrm{AD}+\mathrm{O}_{2}, \mathrm{AD}-\mathrm{O}_{2}, \mathrm{C}+\mathrm{O}_{2}$, and C- $\mathrm{O}_{2}$ (Fig. 2A-D, respectively). Negative controls for RT-PCR were done without reverse transcriptase or template. The y-axis shows the change in fluorescence, whereas the $\mathrm{x}$-axis shows the number of PCR cycles. The point at which the change in fluorescence crosses the threshold (Ct) is used for comparison of the relative abundance of $e d g-1 \mathrm{mRNA}$ in

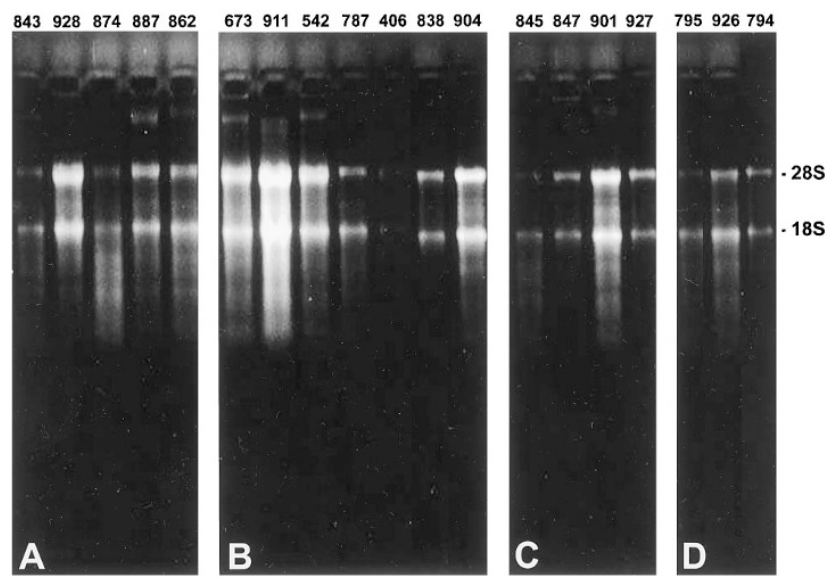

FIGURE 1. A, Agarose gel electrophoresis. Alzheimer's patients who received supplemental oxygen during the agonal period. B, Agarose gel electrophoresis. Control patients who received supplemental oxygen during the agonal period. C, Agarose gel electrophoresis. Alzheimer's patients who did not receive supplemental oxygen during the agonal period. D, Agarose gel electrophoresis. Control patients who did not receive supplemental oxygen during the agonal period. each sample. The threshold is set at 10 times the standard deviation of the mean of the baseline fluorescence collected during Cycles 3-15.

\section{RESULTS}

All samples from the four groups $\left(\mathrm{AD}+\mathrm{O}_{2}\right.$, $\mathrm{AD}-\mathrm{O}_{2}, \mathrm{C}+\mathrm{O}_{2}$, and $\mathrm{C}-\mathrm{O}_{2}$ ) appeared to yield intact RNA as judged by gel electrophoresis (Fig. 1A-D, respectively). Although some lanes were overloaded and showed smearing (Cases 542, 901, 911, and 928) and other lanes were underloaded (Cases 406 and 845), no samples showed significant RNA degradation. The quantitation of total RNA ranged from 190 $\mu \mathrm{g} / \mathrm{g}$ to $1798 \mu \mathrm{g} / \mathrm{g}$. There was no clear correlation of the quantity of total RNA recovered with the interval from death to tissue retrieval. Antemortem factors such as provision of oxygen, fever, or sepsis also seemed to have no direct effect on the amount of total RNA recovered. The $\mathrm{pH}$ of postmortem CSF ranged from 5.9-8.0 and did not correlate with total RNA recovery.

The lowest quantity of total RNA $(190 \mu \mathrm{g} / \mathrm{g})$ was retrieved from the brain most rapidly procured (1 hour and 10 minutes), and the highest quantity of total RNA (1798 $\mu \mathrm{g} / \mathrm{g})$ was obtained from a brain with a postmortem interval of 10 hours and 38 minutes. This difference could be due to several factors unrelated to antemortem factors or postmortem delay. We have found that for quantitating RNA, Ribogreen, an RNA-specific dye, is much more accurate then quantitation using the absorbance of the sample at $260 \mathrm{~nm}$. This may be due to variable copurification of other biological molecules that also absorb at $260 \mathrm{~nm}$. Additionally, this may be a function of the extraction process rather than a true representation of the quality of the tissue. Purification of RNA from brain tissue was quite variable. When using the Qiagen filters for RNA isolation, we ensured that none of the lipid layer on top of the supernatant was added to the columns. This greatly affected RNA binding and recovery from the filters. Extra care must be taken to prevent blocking these filters.

Quantitation of 18S rRNA in each sample was determined using real time RT-PCR and normalized to the amount of 18S rRNA (data not shown). To determine whether these samples could be used for gene expression studies, real time RT-PCR was performed for the edg-1 gene. Within each set of samples, significant patient variability was observed. For example, in the $\mathrm{C}_{-} \mathrm{O}_{2}$ group, Sample 926 showed the highest expression of edg-1, whereas Sample 794 showed the lowest. Assuming that the PCR efficiency is $100 \%$, then Sample 926 expressed 8-fold more edg-1 then Sample 794 and 2-fold more than Sample 795. Similar differences were observed 
A
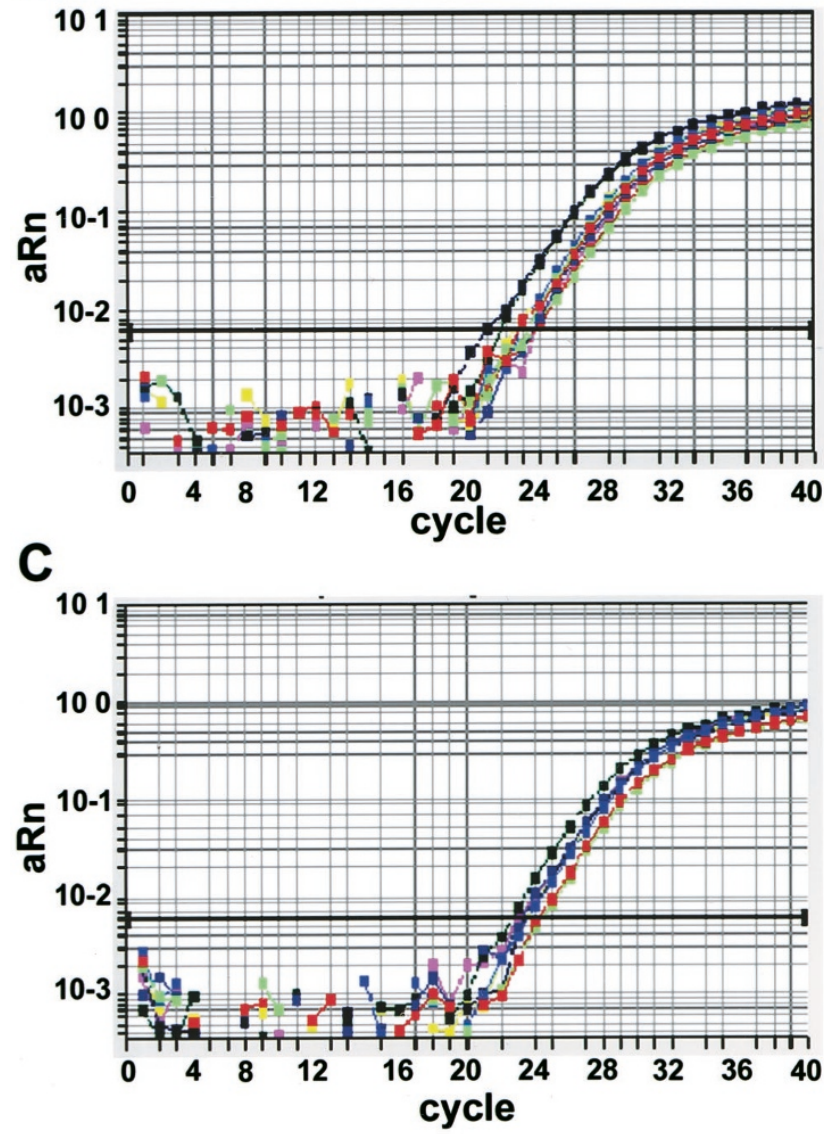

B
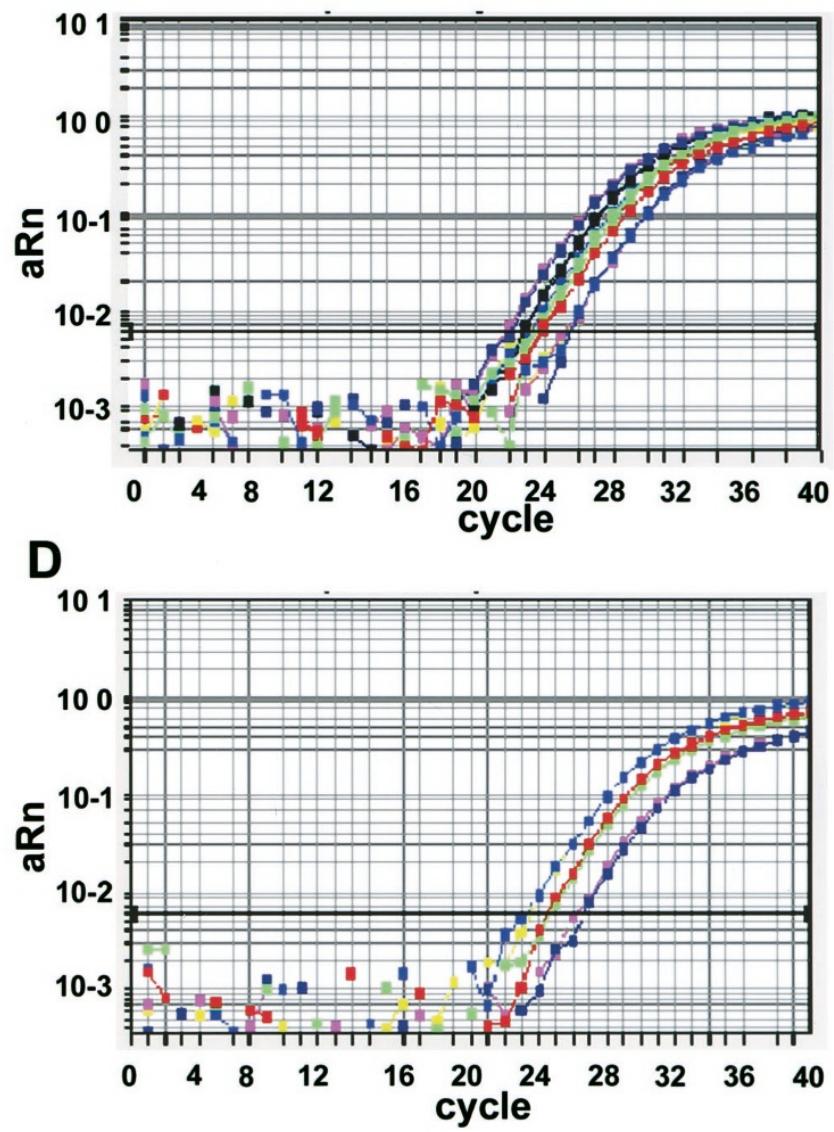

FIGURE 2. A, RT-PCR amplification plot showing expression of edg- 1 mRNA. Human frontal cortex from Alzheimer's patients who received supplemental oxygen during the agonal period. B, Expression of edg- 1 mRNA. Human frontal cortex from control patients who received supplemental oxygen during the agonal period. C, Expression of edg- 1 mRNA. Human frontal cortex from Alzheimer's patients who did not receive supplemental oxygen during the agonal period. D, Expression of edg- 1 mRNA. Postmortem human frontal cortex from control patients who did not receive supplemental oxygen during the agonal period.

within the other sample groups. However, there were no significant differences across these samples groups, suggesting that edg-1 expression was not related to disease, nor was recovery affected by antemortem factors or postmortem delay.

\section{DISCUSSION}

Before the introduction of modern molecular pathology techniques, mRNA was extracted from postmortem human brain tissue and the level of gene expression was analyzed by Northern analysis (2). This technique generally required large quantities of total RNA (as much as 10-20 $\mu \mathrm{g}$ of total RNA per analyses) and was time consuming. The development of real-time RT-PCR allows for the quantitation of gene expression in as little as $25 \mathrm{ng}$ of total RNA, and as many as 96 individual samples can be analyzed in less than two hours. With the rapid progress being made in the development of technologies that allow for expression analysis of genes and proteins, there is currently a tremendous demand for high-quality postmortem human tissue.
Endothelial differentiation gene (EDG) receptors are a family of related G-protein-coupled receptors (GPCRs; 19). GPCRs are integral membrane proteins that participate in chemical neurotransmission $(16,20-22)$. edg- 1 is an immediate-early gene that encodes a GPCR homolog implicated in endothelial cell differentiation (16). Relatively high levels of edg-1 mRNA gene have been detected in neuronal cells and capillaries of adult rodent brain (12, $15,16)$, but its expression has not apparently been described in postmortem adult human brain tissue.

We wanted to determine which factors, if any, were crucial for the recovery of intact RNA from postmortem human brain tissue that could be used for gene expression studies. Prolonged delay to tissue procurement has been presumed to be an important factor in the ability to recover intact mRNA from human autopsy brain tissue. Additionally, AD patients terminally are bedridden with concomitant problems including fever, sepsis, hypoxia, and dehydration with hypotension that may adversely effect biomolecule integrity. In the AD group, intact RNA was recovered in all cases, and expression of 
edg- 1 was detected by real-time RT-PCR in all cases. Similarly, in nondemented control patients, who died of illnesses such as disseminated malignancy, massive gastrointestinal hemorrhage, severe cardiopulmonary disease, and acute myocardial infarction, intact RNA was recovered and edg-1 expression was detected in all cases.

We have shown by real-time RT-PCR the ability to detect edg- 1 mRNA expression in this small sample of postmortem adult human brain tissue. We conclude that mRNA expression can be preserved in patients with prolonged postmortem delays and with diverse clinical variables. We advise, however, that as individual laboratories probe for different genes and their role in myriad pathological processes are investigated, enhanced procurement efforts may become necessary to obtain mRNA with optimal integrity. Variables that may influence mRNA expression in certain genes include cessation of mRNA production at death, variability in the expression of different genes among individuals (11), or technical problems with biomolecule extraction as mentioned in the Results section. A larger patient population may be necessary to further determine the influence of agonal events and procurement delay on biomolecule retrieval.

Acknowledgments: The authors thank Carlyn Rosenberg and Nancy O. Sinclaire for their assistance with data collection.

\section{REFERENCES}

1. Hulette CM, Wesh-Bohmer KA, Crain B, Szymanski MH, Sinclaire NO, Roses AD. Rapid brain autopsy: the Bryan Alzheimer's disease research center experience. Arch Pathol Lab Med 1997;121:615-8.

2. Gilbert JM, Brown BA, Strocchi P, Bird ED, Marotta CA. The preparation of biologically active messenger RNA from human postmortem brain tissue. J Neurochem 1981;36:976-84.

3. Perry EK, Perry RH. Human brain neurochemistry-some postmortem problems. Life Sci 1983;33:1733-43.

4. Bowen DM, Smith CB, White P, Davison AN. Neurotransmitterrelated enzymes and indices of hypoxia in senile dementia and other abiotrophies. Brain 1976;99:459-96.

5. Perry EK, Perry RH, Tomlinson BE. The influence of agonal state on some neurochemical activities in postmortem brain tissue. Neurosci Lett 1982;29:303-8.

6. Florell SR, Coffin CM, Holden JA, Zimmermann JW, Gerwels JW, Summers BK, Jones DA, Leachman SA. Preservation of RNA for functional genomic studies: a multidisciplinary tumor bank protocol. Mod Pathol 2001;14:116-28.
7. Mathern GW, Pretorius JK, Kornblum HI, Mendoza D, Lozada A, Leite JP, Chimelli LM, Fried I, Sakamoto AC, Assirati JA, Levesque MF, Adelson PD, Peacock WJ. Human hippocampal AMPA and NMDA mRNA levels in temporal lobe epilepsy patients. Brain 1997;120:1937-59.

8. Kerfoot C, Wienecke R, Menchine M, Emelin J, Maize JC Jr, Welsh CT, Norman MG, DeClue JE, Vinters HV. Localization of tuberous sclerosis 2 mRNA and its protein product tuberin in normal human brain and in cerebral lesions of patients with tuberous sclerosis. Brain Pathol 1996;6:367-75.

9. Stoffel-Wagner B, Watzka M, Steckelbroeck M, Schramm J, Bidlingmaier JF, Klingmuller D. Expression of 17betahydroxysteroid dehydrogenase types 1,2,3 and 4 in the human temporal lobe. J Endocrinol 1999;160:119-26.

10. Stoffel-Wagner B, Watzka M, Steckelbroeck M, Schramm J, Bidlingmaier JF, Klingmuller D. Expression of CYP19 (aromatase) mRNA in the human temporal lobe. Biochem Biophys Res Commun 1998;244:768-71.

11. Castensson A, Emilsson L, Preece P, Jazin E. High-resolution quantification of specific mRNA levels in human brain autopsies and biopsies. Genome Res 2000;10:1219-29.

12. Liu Y, Wada R, Yamashita T, Mi Y, Deng CX, Hobson JP, Rosenfeldt HM, Nava VE, Chae SS, Lee MJ, Liu CH, Hla T, Spiegel S, Proia RL. Edg-1, the G protein-coupled receptor for sphingosine-1-phosphate, is essential for vascular maturation. J Clin Invest 2000;106:951-61.

13. Hla T. Sphingosine 1-phosphate receptors. Prostaglandins Other Lipid Mediat 2001;64:135-42.

14. Lee MJ, Van Brocklyn JR, Thangada S, Liu CH, Hand AR, Menzeleev R, Spiegel S, Hla T. Sphingosine-1-phosphate as a ligand for the $G$ protein-coupled receptor EDG-1. Science 1998;279:1552-5.

15. Beer MS, Stanton JA, Salim K, Rigby M, Heavens RP, Smith D, McAllister G. EDG receptors as a therapeutic target in the nervous system. Ann N Y Acad Sci 2000;905:118-31.

16. Lado DC, Browe CS, Gaskin AA, Borden JM, MacLennan AJ. Cloning of the rat edg-1 immediate-early gene: expression pattern suggests diverse functions. Gene 1994;149:331-6.

17. Ball M, Braak H, Goethe JW, Coleman P, Dickson D, Duyckaerts C, Gambetti P, Hansen L, Hyman B, Jellinger K, Markesbery W, Perl D, Powers J, Price J, Trojanowski JQ, Wisniewski H. Consensus recommendations for the postmortem diagnosis of Alzheimer's disease. The National Institute on Aging, and Reagan institute working group on diagnostic criteria for the neuropathological assessment of Alzheimer's disease. Neurobiol Aging 1997;18(Suppl 4):S1-2.

18. Braak H, Braak E. Neuropathological staging of Alzheimerrelated changes. Acta Neuropathol 1991;82:239-59.

19. Hla T, Maciag T. An abundant transcript induced in differentiating human endothelial cells encodes a polypeptide with structural similarities to G-protein-coupled receptors. J Biol Chem 1990;265:9308-13.

20. Boege F, Neumann E, Helmreich EJ. Structural heterogeneity of membrane receptors and GTP-binding proteins and its functional consequences for signal transduction. Eur J Biochem 1991;199:1-15.

21. Iismaa TP, Shine J. G-protein-coupled receptors. Curr Opin Cell Biol 1992;4:195-202.

22. Jackson T. Structure and function of G-protein-coupled receptors. Pharmacol Ther 1991;50:425-42. 